\title{
Efficiency of use of supplementary lighting in rearing of dairy calves during milk feeding stage
}

\author{
Gledson L. P. de Almeida ${ }^{1}$, Héliton Pandorf ${ }^{1}$, Fátima Baptista ${ }^{2}$, \\ Cristiane Guiselini ${ }^{1}$, Vasco F. da Cruz ${ }^{2}$ \& Gleidiana A. P. de Almeida ${ }^{3}$ \\ ${ }^{1}$ Departamento de Engenharia Agrícola/Universidade Federal Rural de Pernambuco. Recife, PE. E-mail: gledson@deagri.ufrpe.br (Autor correspondente), \\ pandorfi@deagri.ufrpe.br, cguiseli@hotmail.com \\ ${ }^{2}$ Departamento de Engenharia Rural/Escola de Ciências e Tecnologia, e Instituto de Ciências Agrárias e Ambientais Mediterrânicas/Universidade de \\ Évora. Évora, Portugal. E-mail: fb@uevora.pt, vfc@uevora.pt \\ ${ }^{3}$ Doutorado Integrado em Zootecnia/Universidade Federal Rural de Pernambuco. Recife, PE. E-mail: ameliazootecnia@gmail.com
}

Key words:

animal welfare

dairy cattle

economic viability

\begin{abstract}
A B S T R A C T
The objective of this study was to evaluate programs of supplementary lighting for calves in individual shelters with different roof materials, as a strategy to stimulate concentrate consumption and the reduction of the milk feeding period and increase financial viability. Twenty seven dairy crossed Holstein $\times$ Gir female calves were randomly distributed in individual shelters with three different roofing materials (cement fiber tile, recycled tile and thatched roofs), associated with three different light duration $(12,16$ and $20 \mathrm{~h}$ ) and with three repetitions. The experimental design was completely randomized in $3 \times 3$ factorial arrangement. There was no interaction between the types of roofs $\times$ supplemental light; also, there was no significant effect of the covering types on the average consumption of concentrate and occurance of diarrhea in calves. On the other hand $20 \mathrm{~h}$ of lighting stimulated the consumption of concentrate and allowed weaning of calves at 55 days of age and $20 \%$ reduction in the cost of rearing animals during milk feeding stage.
\end{abstract}

\section{Palavras-chave:}

bem-estar animal bovinocultura de leite viabilidade econômica

\section{Eficiência do uso de iluminação suplementar na criação de bezerras leiteiras durante a fase de aleitamento}

\begin{abstract}
R E S U M O
Objetivou-se, com este trabalho, avaliar programas de iluminação suplementar para bezerras em abrigos individuais, com diferentes materiais de cobertura, como estratégia ao estímulo de consumo de concentrado, redução do período de aleitamento e viabilidade técnico-econômica deste manejo. Foram utilizadas 27 bezerras Girolando distribuídas aleatoriamente em abrigos individuais com três materiais de cobertura (telha de fibrocimento, telha reciclada e cobertura de palha), associados a três tempos de duração de luz $(12,16$ e 20 h), com três repetições. O delineamento adotado foi inteiramente casualizado em arranjo fatorial $3 \times 3$. Não se verificou interação entre os tipos de cobertura $\times$ iluminação suplementar; também não se evidenciou efeito significativo dos tipos de cobertura sobre o consumo médio de concentrado nem ocorrência de diarreia nas bezerras; por outro lado, o tempo de iluminação de 20 h estimulou o consumo de concentrado e possibilitou o desaleitamento das bezerras aos 55 dias de idade e redução de $20 \%$ no custo de criação dos animais na fase de aleitamento.
\end{abstract}




\section{INTRODUCTION}

Dairy cattle is one of the most important segments of Brazilian agriculture and is currently under great transformation as a result of the global economy and the adoption of modern technologies, which will allow to produce more efficiently and be prepared to compete in a global market.

One of the barriers to the potential growth of the dairy industry is attributed to the negligence of producers and the poor management of animal feed, which is often linked to high costs with the rearing of dairy calves during milk feeding and post-weaning, restricting the growth and delaying the onset of puberty in heifers (Bhatti et al., 2012).

Rearing calves for replacement in dairy herds is a phase of high cost and no commercial gain is obtained until the age of the first lactation (Greter et al., 2010). In Brazil, it is common the practice of providing $4 \mathrm{~L}$ of milk per day or 8 to $10 \%$ of calf weight until the age of 60 days (Lopes et al., 2010). However, calves with greater weight gain in the initial phase were earlier in puberty, reducing the age at first calving and increasing productivity per day of animal life, when compared with animals that had lower performance on the initial phase (Soberon et al., 2012). Generally, weaning is performed based on the animal age (typically 60 days) or when the large-size calves is ingesting $0.800 \mathrm{~kg}$ of concentrate for three consecutive days, or when it reaches 90 to $100 \mathrm{~kg}$ live weight (Lopes et al., 2010).

According to Miller-Cushon et al. (2013) to achieve good results on the performance of dairy calves after weaning it is necessary that animals consume satisfactory amounts of solid food before the complete withdrawal of milk. This intake food solid milk feeding during can be stimulated by management systems that adopt gradual weaning methods (Khan et al., 2007) or by social facilitation, promoted by calves housed in groups (De Paula Vieira et al., 2010).

The early intake of concentrate has the beneficial effects of accelerating motility and muscular development of the rumen and having lower incidence of health problems, which enables early weaned animals (Machado Neto et al., 2004).

The supplementary light during lactation has been used to increase milk production in adult animals (Dahl et al., 2000) and to stimulate weight gain in heifers (Tucker et al., 1984) and calves during milk feeding (Osborne et al., 2007). Thus, the supplemental light manipulation consists of a management that could increase the growth and accelerate the onset of puberty in cattle (Schillo et al., 1992).

Accordingly, the aim of this research was to evaluate supplementary lighting programs for calves in individual shelters with different roofing materials, as a strategy to stimulate consumption of concentrate, reduction milk feeding period and the financial viability of such management.

\section{Material AND Methods}

The study was conducted from January to March 2012 during the summer season in the Farm Várzea Alegre, located in the Agreste Region of Pernambuco in Northeast Brazil ( $8^{\circ} 17^{\prime} \mathrm{S}, 36^{\circ} 53^{\prime} \mathrm{W}$ and $800 \mathrm{~m}$ altitude). The region's mean rainfall is $730 \mathrm{~mm}$ per year, mean annual temperature of 24.8 ${ }^{\circ} \mathrm{C}$. According to the Köppen climate classification, the climate is characterized as semi-arid (Bsh).

Twenty-seven crossed Holstein $\times$ Gir female calves that were 15 days old and weighed $40.24 \mathrm{~kg}$ and heart girth $0.79 \mathrm{~m}$ were used in this study. The animals were housed in individual shelters with dimensions of $1.80 \mathrm{~m}$ long, $1.50 \mathrm{~m}$ wide and 1.45 $\mathrm{m}$ height and without side locks. Calves were created in the same area and were able to hear and see the other animals; however, no other type of social contact was possible.

Three different types of roofing materials were evaluated: cement fiber tile, recycled tile (75\% polymer, $25 \%$ aluminium) and thatched roof (palm thatch, Syagrus coronata) used in individual shelters. It was also considered, in the experimental arrangement, the combination of types of roofs with the different light time programs promoted by supplementary lighting: natural light $+4 \mathrm{~h}$ of supplementary lighting (16 h light); natural light $+8 \mathrm{~h}$ of supplementary lighting ( $20 \mathrm{~h}$ light $)$ and natural light (12 h light).

Supplementary lighting was provided by individual lights of $40 \mathrm{~W}$ to provide lighting at an intensity of approximately 415 lumens at the eye level of calves, without affect other adjacent shelters to it. Each shelter was equipped with a lamp fixed to the maximum height of the roof at $1.40 \mathrm{~m}$ from the ground, position that allowed the illumination of the area used by the animal. These lamps were triggered by a timer set to turn on daily at $18 \mathrm{~h}$ (local time), with no light interruption until the end of the period of supplementary lighting for each treatment.

After birth, calves were separated from mothers and taken to the calves housing to be housed in individual shelters. In the first three days of age $4 \mathrm{~L}$ colostrum were given in individual bucket, divided into two daily meals, $2 \mathrm{~L}$ in the morning period $(5 \mathrm{~h})$ and $2 \mathrm{~L}$ in the afternoon period $(17 \mathrm{~h})$, as the management adopted by the farm. Calves had free access to individual feeders and water drinkers and received the same volume of full milk ( $4 \mathrm{~L}$ ) until weaning, also divided into two shifts (morning and afternoon).

Calves had ad libitum access to pelleted concentrate with $18 \%$ crude protein and basic composition of corn, soybean, wheat bran, molasses, rice husk, minerals and vitamins. The food waste was weighed at 6 and $18 \mathrm{~h}$ before each new supply by using a digital scale with $15.0 \mathrm{~kg}$ capacity and $0.002 \mathrm{~kg}$ precision.

The criteria used for calves weaning consisted of evaluating the mean daily intake of concentrate, i.e. when the animals were ingesting $0.800 \mathrm{~kg}$ of concentrate for three consecutive days (Lopes et al., 2010).

The calves were weighed at 15 days age and the moment that could be weaned when the animals were ingesting $0.800 \mathrm{~kg}$ of concentrate for three consecutive days (Lopes et al., 2010). An electronic scale with a capacity of $300.0 \mathrm{~kg}$ and precision of $0.100 \mathrm{~kg}$ with a fixed chute-type containment structure was used. The heart girt was also measured at 15 days age and at the moment that could be weaned.

The climate variables were recorded every hour in each individual shelters and in the exterior, using dataloggers model HOBO U12-12 (Onset Computer Corporation Bourne, MA, USA) to record the dry bulb temperature (DBT) and relative 
humidity $(\mathrm{RH})$. The dataloggers were set inside shelters, positioned at the geometric centre of the facility at a height of $1.40 \mathrm{~m}$. In the exterior, the equipment was installed in a shelter at $1.50 \mathrm{~m}$ from the ground.

To analyse the thermal efficiency of individual shelters, covered with different types of materials, the specific enthalpy $(\mathrm{H})$ was calculated using equation (Eq. 1) proposed by Rodrigues et al. (2010):

$$
\mathrm{H}=1.006 \times \mathrm{DBT}+\frac{\mathrm{RH}}{\mathrm{P}_{\mathrm{atm}}} \times 10^{\left(\frac{7.5 \times \mathrm{DBT}}{237.3+\mathrm{DBT}}\right)} \times(71.28+0.0052 \times \mathrm{DBT})
$$

where:

$\mathrm{H} \quad$ - specific enthalpy, $\mathrm{kJ} \mathrm{kg}^{-1}$ dry air;

DBT - dry bulb temperature, ${ }^{\circ} \mathrm{C}$;

$\mathrm{RH}$ - relative humidity, \%; and

$\mathrm{P}_{\mathrm{atm}}$ - atmospheric pressure, $\mathrm{mmHg}$.

The feces consistency was observed daily to record the occurrence of diarrhea. When considered as normal the value "0 (zero)" was assigned and those as diarrhea, the value "1 (one)." Information related with the control of diarrhea, such as animal number, date of medication, diagnosis and medication carried out were registered. The animals that had diarrhea were treated with medicines made from oxytetracycline dihydrate along with antidiarrheal.

For the economic analysis it was considered the average price of milk paid to producers in the region, average price of hand labor, average price of concentrate, average price of the medicine used in the treatment of diarrhea and the cost with electricity consumption by the supplementary lighting system from the time that the lamps remained turned on throughout the experimental period. The procedures and cost common to all animal (e.g. vitamins, wormers and vaccines) were not considered in the calculations of the cost of setting up the calves during milk feeding stage.

The experimental design was completely randomized in a $3 \times 3$ factorial arrangement with 3 repetions. In total, 27 female's calves were used and were randomly distributed in individual shelters with three roofing materials and three light durations. All of the calves were individually observed throughout the experiment.

The analysis of variance for concentrate intake, body weight and heart girth was performed using Statistical Analysis System software (SAS Inst. Inc., Cary, 2007), using the model Yij $=\mu+$ $\mathrm{Ri}+\mathrm{Lj}+(\mathrm{R} \times \mathrm{L}) \mathrm{ij}+\mathrm{Eij}$, Yij is the value of each observation, $\mu$ is general mean, $\mathrm{Ri}$ is the roof effect $(\mathrm{i}=1,2,3), \mathrm{Lj}$ is effect of light duration $j(j=1,2,3),(R \times L)$ ij is the interaction effect of roof $i$ and light duration $j$, and Eij is the effect of the error associated with each observation. The inferences obtained were evaluated by the Tukey test at 0.05 significance level. The nonparametric variable "diarrhea" was analyzed in terms of the frequency of events and their probability of occurrence using the chi-square test $\left(\mathrm{X}^{2}\right)$. From the records of the frequency was calculated the average number of drug intervention by animal for treatment of diarrhea.

\section{Results AND Discussion}

The thermal environment inside the individual shelters that were covered with recycled tile, thatched roof and cement fiber tile showed little variation with respect to enthalpy. The maximum mean enthalpy values between the roofing materials, were of $62.5,62.5$ and $63.0 \mathrm{~kJ} \mathrm{~kg}^{-1}$ dry air for the shelters covered with recycled tile, thatched roof and cement fiber tile, respectively, at $11 \mathrm{~h}$. The minimum mean enthalpy values between the roofing materials, with values of 52.5, 53.5 and $52.5 \mathrm{~kJ} \mathrm{~kg}^{-1}$ dry air for the shelters covered with recycled tile, thatched roof and cement fiber tile, respectively, at $4 \mathrm{~h}$ (Figure 1).

This low level of variation occurred because the shelters did not have side locks, which favored the largest circulation of inside air. These results corroborate Fiorelli et al. (2009) who found no statistical differences $(\mathrm{P}>0.05)$ for the temperaturehumidity index in husbandry facilities laterally opened and covered with cement fiber tiles and recycled tiles.

There was no significant effect of the roof type on concentrate intake at $3 \mathrm{rd}$ week (cement fiber tile $=0.197 \mathrm{~kg}$ $\mathrm{d}^{-1}$, recycled tile $=0.188 \mathrm{~kg} \mathrm{~d}^{-1}$, thatched roof $=0.133 \mathrm{~kg} \mathrm{~d}^{-1}, \mathrm{P}$ $=0.439$ ), 4 th week (cement fiber tile $=0.290 \mathrm{~kg} \mathrm{~d}^{-1}$, recycled tile $=0.249 \mathrm{~kg} \mathrm{~d}^{-1}$, thatched roof $\left.=0.171 \mathrm{~kg} \mathrm{~d}^{-1}, \mathrm{P}=0.485\right)$, 5th weeks (cement fiber tile $=0.374 \mathrm{~kg} \mathrm{~d}^{-1}$, recycled tile $=0.328 \mathrm{~kg}$ $\mathrm{d}^{-1}$, thatched roof $=0.228 \mathrm{~kg} \mathrm{~d}^{-1}, \mathrm{P}=0.522$ ), 6th week (cement fiber tile $=0.422 \mathrm{~kg} \mathrm{~d}^{-1}$, recycled tile $=0.358 \mathrm{~kg} \mathrm{~d}^{-1}$, thatched roof $=0.243 \mathrm{~kg} \mathrm{~d}^{-1}, \mathrm{P}=0.445$ ), 7 th weeks (cement fiber tile $=$ $0.399 \mathrm{~kg} \mathrm{~d}^{-1}$, recycled tile $=0.317 \mathrm{~kg} \mathrm{~d}^{-1}$, thatched roof $=0.364$ $\mathrm{kg} \mathrm{d}^{-1}, \mathrm{P}=0.389$ ), 8th week (cement fiber tile $=0.603 \mathrm{~kg} \mathrm{~d}^{-1}$, recycled tile $=0.668 \mathrm{~kg} \mathrm{~d}^{-1}$, thatched roof $=0.627 \mathrm{~kg} \mathrm{~d}^{-1}, \mathrm{P}=$ 0.657 ), 9th Week (cement fiber tile $=1.007 \mathrm{~kg} \mathrm{~d}^{-1}$, recycled tile $=1.029 \mathrm{~kg} \mathrm{~d}^{-1}$, thatched roof $=0.853 \mathrm{~kg} \mathrm{~d}^{-1}, \mathrm{P}=0.666$ ) and 10 th weeks of age (cement fiber tile $=1.183 \mathrm{~kg} \mathrm{~d}^{-1}$, recycled tile $=$ $1.200 \mathrm{~kg} \mathrm{~d}^{-1}$, thatched roof $=1.083 \mathrm{~kg} \mathrm{~d}^{-1}, \mathrm{P}=0.832$ ) and no interaction between roof type and supplementary lighting on concentrate intake at $3 r d(P=0.880), 4$ th $(P=0.775), 5$ th $(P$ $=0.772), 6$ th $(\mathrm{P}=0.401), 7$ th $(\mathrm{P}=0.390), 8$ th $(\mathrm{P}=0.349)$, 9th $(\mathrm{P}=0.456)$ and 10 th week of age $(\mathrm{P}=0.737)$. These results are in accordance with studies by Cunha et al. (2007), who also found no significant effects on the average daily consumption of concentrate among calves during milk feeding stage housed in shelters covered with different materials compared with concentrate consumption of calves reared in the open field.

Concerning the supplementary light, there were no significant differences on the mean concentrate consumption

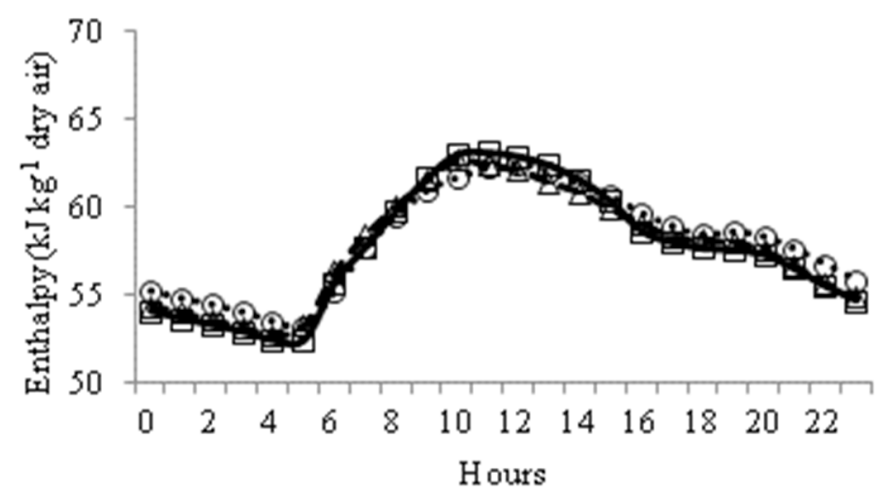

${ }^{1}$ Enthalpy - Specific enthalpy (kJ kg-1 dry air): shelters covered with cement fiber tiles ( $\square$ ); shelters covered with recycled tiles $(\Delta)$ and shelters covered with roofs with thatched $(0)$ Figure 1. Variation of specific enthalpy within individual shelters with different types of coverage recorded during the experimental period 
for calves exposed to 12,16 and $20 \mathrm{~h}$ light from the $3 \mathrm{rd}$ to the 7 th week of age. However, from the 8 th to the 10 th week of age, significant differences were found $(\mathrm{P}<0.05)$ for calves subjected to $20 \mathrm{~h}$ light compared to calves that had no access to artificial lighting (Table 1).

Calves with $20 \mathrm{~h}$ of lighting consumed more concentrate than the others which can be due to the fact they had more available light which contributed to stimulate ingestion of food. In fact, all calves were milk fed by the end of the afternoon $(17 \mathrm{~h})$, according with farm management, were satiated and did not try to eat more in the beginning of the night. This result disagrees with Bustos Mac-Lean (2012), who found no difference in concentrate intake between calves exposed to 12 and $18 \mathrm{~h}$ light, in which the supplementary lighting was thrown from $0 \mathrm{~h}$ (zero) until the beginning natural light, possibly because this light interval had coincided with the time when the animals spent most of their time sleeping.

The study by Osborne et al. (2007) showed that calves exposed to long photoperiods (16 to $18 \mathrm{~h}$ of light), receiving four $\mathrm{L}$ of milk twice a day had higher intake of concentrate than animals exposed to short photoperiod (10 to $12 \mathrm{~h}$ of light) using fluorescent lights to provide lighting at intensity of approximately 600 lumens at the level of the calves' eye. However, the authors state that there was no difference in concentrate intake from 0 to 28 days of age. Usually, calves show no significant weight gain at this age (2nd to 3 rd weeks) due to several rumen challenges that include development, health, environmental changes and nutrient intake (Davis \& Drackley, 1998; Diaz et al., 2001).

The daily mean intake of concentrate higher than 0.800 $\mathrm{kg}$ for three consecutive days was observed on the 8 th week at 55 days of age in calves subjected to $20 \mathrm{~h}$ light; in this week the calves have consumed on average $0.952 \mathrm{~kg}$ of concentrate per day, followed by animals with $16 \mathrm{~h}$ light daily, which met the criteria of weaning on the 9th week at 61 days of age and consumed on average $0.845 \mathrm{~kg}$ of concentrate per day. Calves with no supplementary lighting ( $12 \mathrm{~h}$ light) started consuming $0.800 \mathrm{~kg}$ of concentrate for three consecutive days, only on the 10th week at 66 days of age, ingesting $0.881 \mathrm{~kg}$ of concentrate per day (Table 1).

There was no association of the roof type on occurrence of diarrhea (cement fiber tile $=1.44$ drug intervention animal ${ }^{-1}$, recycled tile $=1.66$ drug intervention animal ${ }^{-1}$, thatched roof $=1.44$ drug intervention animal ${ }^{-1}, \mathrm{P}=0.904$ ) by chi-square test and no interaction between roof type and supplementary lighting on concentrate intake $(\mathrm{P}>0.05)$,
The chi-square test showed that the occurrence of diarrhea depended on the lighting time (Table 2) and is related to the intake of concentrated. It was found that the calves without access to supplementary lighting (12 h light) had higher incidence of diarrhea during milk feeding stage, with 19 (3.8\%) observations of diarrheal feces, followed by calves subjected to 16 and $20 \mathrm{~h}$ light that showed $17(3.3 \%)$ and $4(0.8 \%)$ observations during the experimental period. These results indicate the need for $2.11,1.88$ and 0.44 pharmacological interventions per animal for the treatment of diarrhea, respectively, for calves without access to supplementary lighting ( $12 \mathrm{~h}$ light) with $4 \mathrm{~h}$ supplementary lighting ( $16 \mathrm{~h}$ light) and $8 \mathrm{~h}$ supplementary lighting ( $20 \mathrm{~h}$ light), as shown in Table 2.

These results corroborate searches made by McKnight (1978) who analysed the performance of Holstein calves in temperate region and Cunha et al. (2007), who studied the performance of crossbred Holstein $\times$ Zebu calves in tropical regions. Both authors found decreases in the occurrence of diarrhea in animals that consumed higher amounts of concentrate and therefore, less need for drug intervention compared to animals that consumed less amount of concentrate during milk feeding stage. Thus, when animals are affected in incidences of illness there is need for treatment, increasing the costs with drugs and even technical consulting (Guerra et al., 2010).

The lower incidence of diarrhea in calves may be related to the good health of the animals due to appropriate environmental and sanitary conditions and also because of the greater absorption of nutrients, which contributes to greater resistance to disease (Gonçalves et al., 2000). Thus, the lower incidence of diarrhea observed in calves subjected to $20 \mathrm{~h}$ lighting (Table 2) compared to those without supplementary lighting may be associated with greater intake of concentrate (Table 1), with greater ability to absorb nutrients, resistance to the incidence of diarrhea and reduced cost of medications (Table 3 ). The

Table 2. Frequency of occurrence and need for medical intervention for treatment of diarrhea in calves during the experimental period

\begin{tabular}{cccccc}
\hline Light & \multicolumn{3}{c}{ Observations } & $\begin{array}{c}\text { Number } \\
\text { duration }\end{array}{ }^{1}$ & $\begin{array}{c}\text { Drug intervention } \\
\text { animal- }^{-1}\end{array}$ \\
\cline { 2 - 5 } $12 \mathrm{~h}$ & 485 & 19 & 504 & 9 & 2.11 \\
$16 \mathrm{~h}$ & 487 & 17 & 504 & 9 & 1.88 \\
$20 \mathrm{~h}$ & 500 & 4 & 504 & 9 & 0.44 \\
$\mathrm{X}^{2}=10.579$ & & & & & $\mathrm{P}=0.005$ \\
\hline
\end{tabular}

'Light duration: $12 \mathrm{~h}=12 \mathrm{~h}$ of natural light; $16 \mathrm{~h}=12 \mathrm{~h}$ of natural light $+4 \mathrm{~h}$ of supplementary lighting; $20 \mathrm{~h}=12 \mathrm{~h}$ of natural light $+8 \mathrm{~h}$ of supplementary lighting

Table 1. Daily mean values and standard deviation of concentrate intake during the weeks assessed during milk feeding stage

\begin{tabular}{|c|c|c|c|c|}
\hline \multirow{2}{*}{$\begin{array}{c}\text { Daily mean intake } \\
\text { of concentrate in weeks }(\mathrm{kg})\end{array}$} & \multicolumn{3}{|c|}{ Light duration ${ }^{1}(\mathrm{~h})$} & \multirow{2}{*}{ P-value } \\
\hline & 12 & 16 & 20 & \\
\hline 3 weeks of age & $0.183 \pm 0.097 \mathrm{a}$ & $0.127 \pm 0.074 a$ & $0.208 \pm 0.127 a$ & 0.332 \\
\hline 4 weeks of age & $0.248 \pm 0.210 a$ & $0.164 \pm 0.083 a$ & $0.300 \pm 0.230 a$ & 0.403 \\
\hline 5 weeks of age & $0.291 \pm 0.219 a$ & $0.232 \pm 0.125 a$ & $0.407 \pm 0.249 a$ & 0.412 \\
\hline 6 weeks of age & $0.273 \pm 0.239 a$ & $0.329 \pm 0.232 a$ & $0.422 \pm 0.289 a$ & 0.368 \\
\hline 7 weeks of age & $0.296 \pm 0.224 \mathrm{a}$ & $0.308 \pm 0.203 \mathrm{a}$ & $0.523 \pm 0.321 \mathrm{a}$ & 0.134 \\
\hline 8 weeks of age & $0.431 \pm 0.293 a$ & $0.516 \pm 0.265 a b$ & $0.952 \pm 0.399 b$ & 0.040 \\
\hline 9 weeks of age & $0.740 \pm 0.386 a$ & $0.845 \pm 0.346 a b$ & $1.305 \pm 0.439 b$ & 0.035 \\
\hline 10 weeks of age & $0.881 \pm 0.382 \mathrm{a}$ & $1.156 \pm 0.368 a b$ & $1.431 \pm 0.423 b$ & 0.047 \\
\hline
\end{tabular}

a-bMeans within a row with different superscripts differ $(P<0.05)$; ${ }^{1}$ Light duration: $12 \mathrm{~h}=12 \mathrm{~h}$ of natural light; $16 \mathrm{~h}=12 \mathrm{~h}$ of natural light $+4 \mathrm{~h}$ of supplementary lighting; $20 \mathrm{~h}=12 \mathrm{~h}$ of natural light $+8 \mathrm{~h}$ of supplementary lighting 
reduced need for drug intervention $\left(0.44\right.$ unit animal $\left.^{-1}\right)$ for treatment of diarrhea in calves with $20 \mathrm{~h}$ light contributed to $\mathrm{R} \$$ 18.28 reduction on the total cost of rearing the calf during milk feeding stage compared to that reared without supplementary lighting (Table 3).

The total of concentrated calculated for each animal from 15 days of age, until they reach the age at which the consumption exceeded $0.800 \mathrm{~kg}$ for three consecutive days, was not significantly different $(\mathrm{P}=0.780)$ and showed values of approximately $18.920 \pm 7.688,14.973 \pm 6.301$ and 17.512 $\pm 7.571 \mathrm{~kg}$, respectively, for calves subjected to 12,16 and 20 $\mathrm{h}$ daily light (Table 3 ). The higher concentrate consumption by the calves with $12 \mathrm{~h}$ light is explained by the longer period of milk feeding (66 days). On the other hand the higher concentrate consumed by the calves with $20 \mathrm{~h}$ light compared with those with $16 \mathrm{~h}$ is explained by the fact that these animals started the ingestion of concentrate early. Production costs were 17.03 ; 13.48 and $15.76 \mathrm{R} \$$ per animal, respectively for 12, 16 and $20 \mathrm{~h}$ lighting, as shown in Table 3.

One of the most important aspects when rearing calves is the cost of the concentrate, which is almost always lower than the milk price used to feed the animals. Furthermore, from the moment the animals have satisfactory concentrate intake, according to Lopes et al. (2010), the liquid food (milk or milk replacer) has minor importance on the dry matter intake and animal performance, which allows its weaning and consequent cost reduction in rearing (Almeida Júnior et al., 2008). This was also demonstrated in this study, where calves with $20 \mathrm{~h}$ light could be weaning with age of 55 days, which contributed to decrease milk consumption and in consequence production costs during the milking phase (Table 3 ).

Weaning calves subjected to 20,16 and $12 \mathrm{~h}$ of light could be done at 55, 61 and 66 days of age, respectively, when the animals began to ingest $0.800 \mathrm{~kg}$ concentrate for three consecutive days. This allowed reduction in the milk supply of $44 \mathrm{~L}$ for animals exposed to $20 \mathrm{~h}$ light and, reduction of $20 \mathrm{~L}$ of milk to calves

Table 3. Values, consumption and costs of hand labor, electricity, whole milk, concentrate, drugs and total cost for rearing a calve during milk feeding stage with different durations of light

\begin{tabular}{|c|c|c|c|}
\hline \multirow{2}{*}{ Variables } & \multicolumn{3}{|c|}{ Light duration ${ }^{1}(\mathrm{~h})$} \\
\hline & 12 & 16 & 20 \\
\hline Value of hand labor $\left(\mathrm{R} \$ \mathrm{~d}^{-1}\right)$ & 0.270 & 0.270 & 0.270 \\
\hline Value of electricity $\left(\mathrm{R} \$ K W \mathrm{~h}^{-1}\right)$ & 0.000 & 0.233 & 0.233 \\
\hline Value of whole milk $\left(\mathrm{R} \$ \mathrm{~L}^{-1}\right)$ & 0.95 & 0.95 & 0.95 \\
\hline Value of concentrate $\left(\mathrm{RS} \mathrm{kg}^{-1}\right)$ & 0.90 & 0.90 & 0.90 \\
\hline Value of drug $\left(R \$\right.$ dose $\left.^{-1}\right)$ & 10.95 & 10.95 & 10.95 \\
\hline Consumption of hand labor animal ${ }^{-1}$ (Days) & 66 & 61 & 55 \\
\hline Consumption of electricity animal ${ }^{-1}$ (KWh) & 0.00 & 9.76 & 17.60 \\
\hline Consumption of milk animal ${ }^{-1}(\mathrm{~L})$ & 264 & 244 & 220 \\
\hline Consumption of concentrate animal ${ }^{-1}(\mathrm{~kg})$ & 18.920 & 14.973 & 17.512 \\
\hline Consumption of drug animal ${ }^{-1}$ (Application) & 2.11 & 1.88 & 0.44 \\
\hline Cost of hand labor animal ${ }^{-1}(\mathrm{R} \$)$ & 17.82 & 16.47 & 14.85 \\
\hline Cost of electricity animal ${ }^{-1}(\mathrm{R} \$)$ & 0.00 & 2.27 & 4.10 \\
\hline Cost of milk animal ${ }^{-1}(\mathrm{R} \$)$ & 250.80 & 231.80 & 209.00 \\
\hline Cost of concentrate animal ${ }^{-1}(\mathrm{R} \$)$ & 17.03 & 13.48 & 15.76 \\
\hline Cost of drugs animal ${ }^{-1}(\mathrm{R} \$)$ & 23.10 & 20.58 & 4.82 \\
\hline Total cost animal $^{-1}(\mathrm{R} \$)$ & 308.75 & 284.61 & 248.53 \\
\hline
\end{tabular}

'Light duration: $12 \mathrm{~h}=12 \mathrm{~h}$ of natural light; $16 \mathrm{~h}=12 \mathrm{~h}$ of natural light $+4 \mathrm{~h}$ of supplementary light; $20 \mathrm{~h}=12 \mathrm{~h}$ of natural light $+8 \mathrm{~h}$ of supplementary light; Value of the dollar during the experimental period: US\$1 $=\mathrm{R} \$ 1.79$ subjected to $16 \mathrm{~h}$ light compared with the $12 \mathrm{~h}$ light, in which calves consumed $264 \mathrm{~L}$ of milk until weaning.

During the period that lamps were turned on for illumination of the individual shelters for animals exposed to $16 \mathrm{~h}$ of light ( $4 \mathrm{~h}$ supplementary lighting; 61 days) and more $20 \mathrm{~h}$ of light ( $8 \mathrm{~h}$ supplementary lighting; 55 days), 9.76 and 17.6 KWh of electricity per calves were spent, respectively. This resulted in electricity costs in the amount of $\mathrm{R} \$ 4.10$ and $\mathrm{R} \$ 2.27$ for animals with $8 \mathrm{~h}$ (20 h light) and $4 \mathrm{~h}$ ( $16 \mathrm{~h}$ light $)$ supplementary lighting, respectively (Table 3 ). However, it was found that animals without supplementary lighting had higher incidence of diarrhea and, consequently, there was greater expense with drug treatments. Comparing the costs of medicines for treatment of diarrhea, there was a reduction of $\mathrm{R} \$ 2.52$ and $\mathrm{R} \$ 18.28$ occurred in calves subjected to 16 and 20 h light, respectively (Table 3 ).

During the milk feeding stage, daily costs are higher than during any other phase of rearing the dairy cattle, and this is due in part to the high cost of milk plus the expenses relating to the handling of animals (Davis \& Drackley, 1998). The rearing of calves increases the cost of milk production, especially when the milk is supplied for long periods (Rocha et al., 1999).

In this study it was found that the costs for rearing a calves with natural light $+8 \mathrm{~h}$ of supplementary lighting ( $20 \mathrm{~h}$ light) and natural light $+4 \mathrm{~h}$ of supplementary lighting (16 h light) were approximately $\mathrm{R} \$ 57.25$ and $\mathrm{R} \$ 22.80$, which are lower than the cost for rearing a calves without supplemental lighting (12 h light). Thus, the use of supplemental lighting for $8 \mathrm{~h}(20 \mathrm{~h}$ light) can be adopted as appropriate management to stimulate the consumption of concentrate by calves during milk feeding, with satisfactory development and allowing the producer to reduce costs of rearing calves for herd replacement during milk feeding stage. The cost reduction was approximately $20 \%$ using $20 \mathrm{~h}$ light in comparison to animals that received no supplementary lighting, which is in agreement with previous study by Vasconcelos et al. (2009).

There was no significant effect of the roof type on body weight (cement fiber tile $=66.833 \mathrm{~kg}$, recycled tile $=67.256 \mathrm{~kg}$, thatched roof $=67.544 \mathrm{~kg}, \mathrm{P}=0.985$ ) and heart girth (cement fiber tile $=0.932 \mathrm{~m}$, recycled tile $=0.917 \mathrm{~m}$, thatched roof $=$ $0.913 \mathrm{~m}, \mathrm{P}=0.625)$, and no interaction between roof type and supplementary lighting on body weight $(\mathrm{P}=0.413)$ and heart girth $(\mathrm{P}=0.281)$ the moment which could be weaned according to the daily concentrated intake (Table 2) when animals ingesting $0.800 \mathrm{~kg}$ of concentrate for three consecutive days, as recommended by Lopes et al. (2010). Also no significant difference was observed $(\mathrm{P}>0.05)$ between body weight of the calves exposed to $20 \mathrm{~h}$ light when they could be weaned at 55 days of age when compared with calves under 16 and $12 \mathrm{~h}$ light (Table 4), which respectively, could be weaned at 61 and 66 days age according to the daily intake of concentrated as recommended by Lopes et al. (2010). This result agrees with Osborne et al. (2007) that found higher body weight in calves that consumed more concentrated when exposed to longer duration of light.

The measurements of heart girth recorded to 66, 61 and 55 days of age were not different $(\mathrm{P}>0.05)$ in animals exposed to 12,16 and $20 \mathrm{~h}$ of light, respectively (Table 4 ). These results 
Table 4. Mean values and standard deviations of body weight and heart girth of females calves in the moment that could be weaned exposed to different light durations

\begin{tabular}{cccc}
\hline \multirow{2}{*}{$\begin{array}{c}\text { Performance } \\
\text { of calves }\end{array}$} & \multicolumn{3}{c}{ Light duration $^{1}(\mathrm{~h})$} \\
& (66 days age) & (61 days age) & (55 days age)
\end{tabular}

Body $\quad 66.800 \pm 6.73766 .389 \pm 6.79268 .444 \pm 7.754 \quad 0.870$

$\begin{array}{lllll}\text { weight }(\mathrm{kg}) & 0.900 \pm 0,030 & 0.931 \pm 0.040 & 0.930 \pm 0.060 & 0.278\end{array}$

girth (m)

'Light duration: $12 \mathrm{~h}=12 \mathrm{~h}$ of natural light; $16 \mathrm{~h}=12 \mathrm{~h}$ of natural light $+4 \mathrm{~h}$ of supplementary light; $20 \mathrm{~h}=12 \mathrm{~h}$ of natural light $+8 \mathrm{~h}$ of supplementary light

explained by the efficiency of the use of supplementary lighting in creation of calves during milk feeding stage, which promoted satisfactory performance in the animals and could be weaning earlier.

\section{Conclusions}

1. Calves exposed to $8 \mathrm{~h}$ lighting supplementary ( $20 \mathrm{~h}$ light) were stimulated to consume higher amounts of concentrate, caused reduction in the occurrence of diarrhea and allowing weaning at 55 days of age, without impair performance of calves.

2. The use of $8 \mathrm{~h}$ supplementary lighting daily ( $20 \mathrm{~h} \mathrm{light)}$ allowed $20 \%$ reduction in the cost of animals rearing during milk feeding stage.

\section{ACKNowledgement}

To the Coordenação de Aperfeiçoamento de Pessoal de Nível Superior (CAPES), Process $N^{\circ}$. 18530-12-5 for the scholarship to conducting the doctoral internship abroad (University of Évora).

\section{Literature Cited}

Almeida Júnior, G. A.; Costa, C.; Carvalho, S. M. R.; Panichi, A.; Persichetti Júnior, P. Desempenho de bezerros holandeses alimentados até o desaleitamento com silagem de grãos úmidos ou grãos secos de milho ou sorgo. Revista Brasileira de Zootecnia, v.37, p.140-147, 2008. http://dx.doi.org/10.1590/ S1516-35982008000100021

Bhatti, S. A.; Ali, A.; Nawaz, H.; Mcgill, D.; Sarwar, M.; Afzal, M.; Khan, M. S.; Ehsanullah; Amer, M. A.; Bush, R.; Wynn, P. C.; Warriach, H. M. Effect of pre-weaning feeding regimens on postweaning growth performance of Sahiwal calves. International Journal of Animal Bioscience, v.6, p.1231-1236, 2012. http:// dx.doi.org/10.1017/S1751731112000250

Bustos Mac-Lean, P. A. Programa de suplementação de luz e relações entre variáveis fisiológicas e termográficas de bezerros em aleitamento em clima quente. Pirassununga: FZEA/USP, 2012. 103p. Tese Doutorado

Cunha, D. N. F. V.; Campos, O. F.; Pereira, J. C.; Pires, M. F. A.; Oliveira, R. F. M.; Martuscello, J. A. Desempenho, variáveis fisiológicas e comportamento de bezerros mantidos em diferentes instalações: época seca. Revista Brasileira de Zootecnia, v.6, p.847-854, 2007. http://dx.doi.org/10.1590/S1516-35982007000400014
Dahl, G. E.; Buchanan, B. A.; Tucker, H. A. Photoperiod effects on dairy cattle: A review. Journal of Dairy Science, v.83, p.885-893, 2000. http://dx.doi.org/10.3168/jds.S0022-0302(00)74952-6

Davis, C. L.; Drackley, J. K. The development, nutrition and management of the young calf. Ames: Iowa State University, 1998. 339p.

De Paula Vieira, A.; Von Keyserlingk, M. A. G.; Weary, D. M. Effects of pair versus single housing on performance and behavior of dairy calves before and after weaning from milk. Journal of Dairy Science, v.93, p.3079-3085, 2010. http://dx.doi.org/10.3168/ jds.2009-2516

Diaz, M. C.; Van Amburgh, M. E.; Smith, J. M.; Kelsey, J. M.; Hutten, E. L. Composition of growth of Holstein calves fed milk replacer from birth to 105 kilogram body weight. Journal of Dairy Science, v.84, p.830-842, 2001. http://dx.doi.org/10.3168/jds.S00220302(01)74541-9

Fiorelli, J.; Morceli, J. A. B.; VAZ, R. I.; Dias, A. A. Avaliação da eficiência térmica da telha reciclada à base de embalagens longa vida. Revista Brasileira de Engenharia Agrícola e Ambiental, v.13, p.204-209, 2009. http://dx.doi.org/10.1590/S1415-43662009000200015

Gonçalves, G. D.; Santos, G. T.; Rigolon, L. P.; Damasceno, J. C.; Ribas, N. P.; Veiga, D. R.; Martins, E. N. Influência da adição de probióticos na dieta sobre o estado sanitário e desempenho de bezerros da raça Holandês. Brazilian Journal of Veterinary Research and Animal Science, v.37, p.1-7, 2000. http://dx.doi. org/10.1590/S1413-95962000000100013

Greter, A. M.; Leslie, K. E.; Mason, G. J.; Mcbride, B. W.; Devries, T. J. Effect of feed delivery method on the behavior and growth of dairy heifers. Journal of Dairy Science, v.93, p.1668-1676, 2010. http://dx.doi.org/10.3168/jds.2009-2844

Guerra, M. G.; Guilhermino, M. M.; Rangel, A. H. N.; Medeiros, H. R.; Lima Júnior, D. M. Custo operacional total na cria e recria de bovinos leiteiros. Revista Verde de Agroecologia e Desenvolvimento Sustentável, v.5, p.172-178, 2010.

Khan, M. A.; Lee, H. J.; Lee, W. S.; Kim, H. S.; Kim, S. B.; Ki, K. S.; Ha, J. K.; Lee, H. G.; Choi, Y. J. Pre-and postweaning performance of Holstein female calves fed milk through step-down and conventional methods. Journal of Dairy Science, v.90, p.876-885, 2007. http://dx.doi.org/10.3168/jds.S0022-0302(07)71571-0

Lopes, F. C. F.; Carneiro, J. C.; Gama, M. A. S. Alimentação. In: Auad, Santos, A. M.; Carneiro, A. M. B.; Ribeiro, A. V.; Oliveira, V. M.; Rocha, W. S. D. (ed.) Manual de bovinocultura de leite. Brasília: EMBRAPA, 2010. p.351-394.

Machado Neto, R.; Faroni, C. E.; Pauletti, P.; Bessi, R. Levantamento do manejo de bovinos leiteiros recém-nascidos: desempenho e aquisição de proteção passiva. Revista Brasileira de Zootecnia, v.33, p.2323-2329, 2004. http://dx.doi.org/10.1590/S151635982004000900019

McKnight, D. R. Performance of newborn dairy calves in hutch housing. Canadian Journal of Animal Science, v.58, p.517-520, 1978. http://dx.doi.org/10.4141/cjas78-066

Miller-Cushon, E. K.; Bergeron, R.; Leslie, K. E.; Devries, T. J. Effect of milk feeding level on development of feeding behavior in dairy calves. Journal of Dairy Science, v.96, p.551-564, 2013. http:// dx.doi.org/10.3168/jds.2012-5937

Osborne, V. R.; Odongo, N. E.; Edwards, A. M.; Mcbride, B. W. Effects of photoperiod and glucose-supplemented drinking water on the performance of dairy calves. Journal of Dairy Science, v.90, p.5199-5207, 2007. http://dx.doi.org/10.3168/jds.2007-0402 
Rocha, E. O.; Fontes, C. A. A.; Paulino, M. F.; Pereira, J. C.; Ladeira, M. M. Influência da idade de desmama e de início do fornecimento de volumoso a bezerros sobre a digestibilidade de nutrientes e o balanço de nitrogênio, pós-desmama. Revista Brasileira de Zootecnia, v.28, p.143-147, 1999. http://dx.doi.org/10.1590/S1516-35981999000100022

Rodrigues, V. V.; Silva, I. J. O.; Vieira, F. M. C.; Nascimento, S. T. A correct enthalpy relationship as thermal comfort índex for livestock. International Journal of Biometeorology, v.1, p.455459, 2010.

SAS Institute. User's guide: Statistics. Version 8. (ed.) SAS Institute Inc., Cary, 2007.

Schillo, K. K.; Hall, J. B.; Hileman, S. M. Effects of nutrition and season on the onset of puberty in the beef heifer. Journal of Animal Science, v.70, p.3994-4005, 1992.
Soberon, F.; Raffrenato, E.; Everett, R. W.; Van Amburgh, M. E. Preweaning milk replacer intake and effects on long-term productivity of dairy calves. Journal of Dairy Science, v.95, p.783793, 2012. http://dx.doi.org/10.3168/jds.2011-4391

Tucker, H. A.; Petitclerc, D.; Zinn, S. A. The influence of photoperiod on body weight gain, body composition, nutrient intake and hormone secretion. Journal of Animal Science, v.59, p.16101620, 1984.

Vasconcelos, A. M.; Moraes, D. A. E. F.; Olivo, C. J.; Farias, D. A.; Saenz, E. A. C.; Landim, A. V.; Gomes, T. C. L.; Rogério, M. C. P.; Goés, K. L. S.; Nascimento, J. R.; Oliveira Júnior, A. A. Desempenho de bezerros leiteiros submetidos a diferentes dietas líquidas e instalações durante o período hibernal. Acta Veterinaria Brasílica, v.3, p.163-171, 2009. 